\title{
Development of youth initiative upon studying socio-cultural space of a metropolis
}

\author{
Galina Sorokovykh ${ }^{1 *}$, Lyubov Bannikova ${ }^{1}$, Natalia Pribylova $^{2}$, Svetlana Staritsyna ${ }^{2}$, and \\ Yekaterina Vishnevskaya ${ }^{3}$ \\ ${ }^{1}$ Moscow City University, Institute of Foreign Languages, Department of the French Language and \\ Linguodidactics, Moscow, Russia \\ ${ }^{2}$ Moscow City University, Institute of Foreign Languages, Department of the English Language and \\ Cross-Cultural Studies, Moscow, Russia \\ ${ }^{3}$ Moscow City University, Institute of Foreign Languages, Department of Linguistics and Translation \\ Studies, Moscow, Russia
}

\begin{abstract}
Due to wide-scale introduction of distance learning, the education sphere faces new social and psychological problems related with self-actualization, improvement of intelligence level, and spiritual development of youth and students. Today, the young teacher is a bearer of a unique subculture, the holder of a special personal position, which is characterized by the active nature of consciousness, understanding of the importance of personal initiative in the education of the generation. We consider the student as a representative of young people, who is a carrier of cognitive activity, owning ways of interacting with social reality, including personal initiative. The status of a student of a pedagogical university in Moscow plays an important role in creating a certain socio-cultural environment of the metropolis. Research objective is to substantiate and diversify interdepartmental experience of the Institute of Foreign Languages in development of initiative and activity of students during studying sociocultural space of the capital. This article presents the training experience of future teachers, which can be used in university educational environment, as well as illustrative examples confirming appropriateness and consistency of educational policy of Institute of Foreign Languages, Moscow City University, in this direction. The research is based on generalization of teaching experience in training teachers of the English language and theoretical methodological provisions described by leading Russian and foreign researchers. This research generalizes the most efficient methods and skills of development of youth initiative upon designing and implementation of authors' projects of study of socio-cultural space of Moscow, the toolkit for support of students' projects is presented. The importance of development of youth initiative for formation of sociocultural competence of teacher and his self-education has been proven.

Keywords: designing authors' initiative projects, socio-cultural practices, future teachers.
\end{abstract}

* Corresponding author: sorokovykh@mail.ru 


\section{Introduction}

The importance of this research is stipulated by the trends of modern Russian society, which by means of education system influence formation of persons ready for active consc ious life and acting as subjects of dialogue of cultures. Culture itself is an adaptive tool [1].

Formation of urban consciousness takes place in a specific living space, combination of objects of human activity, requiring for analysis and studying. This evidences the necessity to enhance axiological aspect of targets and content of education aiming at development of worldview and value orientations [2, p. 15]. Federal State Standard of Higher Education $(3++)$ states important requirements to formation of universal competences of graduates, such as ability to work in team, comprehension of intercultural variety of society in social and historical, ethic and philosophical contexts [3]. One of the structural units of the standard is learning practice aimed at development of project and cultural and educational skills, as well as used to bridge the gap between formal education curriculum and practice requirements [4]. Taking into consideration the realities of multiethnical multinational metropolis, the problem of multicultural education of a modern specialist acquires particular importance, for whom it is important to demonstrate high level of communicative and general cultural competence in discussion of this or that topic [5, p. 19].

Using languages and cultures, it is necessary to influence the student's personality aiming at formation of its peculiar properties providing efficiency of active interaction with a representative of native or other linguistic social environment under various conditions of intercultural communication in order to solve various issues of professional and/or cultural socialization [6, p. 59].

Current pedagogical reality is such that it is required to consider in education, on the one hand, ethnocultural factor, and on the other hand, creation of organizational and methodological, and psychological and pedagogical conditions for cognition of culture of other nations [7, pp. 27-28].

Therefore, the aim of this article is to review and to substantiate the experience of the Institute of Foreign Languages in development of initiative of students of pedagogical university in mastering and translation of material and cultural resources of metropolis in the frames of socio-cultural practice.

During the research the following problems were formulated and solved:

1) to identify the most relevant areas of development of the city's resources in the context of educational practices,

2) to determine the role and position of socio-cultural practice in implementation of professional training of students of pedagogical university,

3) to develop and to present toolkit for support of youth initiatives.

The formulated problems were solved using the following research methods: analysis of regulatory documents, linguistic and didactic publications on the considered problem; pedagogical simulation; generalization of pedagogic experience in training future teachers of the English language; analysis of the results of students' activities.

Theoretical foundation of the research was comprised of the works of leading Russian and foreign researchers devoted to general issues:

- professional training of modern teacher in the context of subject-subject approach (S.L. Rubinshtein [8], G.V. Sorokovykh [9], I.S. Yakimanskaya [10], T.I. Shamova [11]),

- socio-cultural and intercultural approaches in education (Ye.G. Tareva [6], P.V. Sysoev [12], Maslow A.H. [13], Heidegger M. [14], etc.).

Practical importance of the research. The described theoretical and practical potential of studying socio-cultural space of metropolis by students can be used for efficient training not only of graduates of the Institute of Foreign Languages, but also for specialists of other fields. 


\section{Results}

This work analyzes the results of practices, which mainly determine the content of activity and initiative of future teacher of foreign language. Opportunities abound for higher education programs to engage external, community-based organizations in fulfilling the goal of providing culturally-relevant degrees [15]. Therefore, the initiative of a future teacher of foreign language can be presented as:

- qualitative property of a teacher in adoption of socio-cultural values,

- method of formation of pedagogic skills, capacities to evaluate critically native and other cultures,

- socially meaningful personal basis of own existence,

- method of interaction of young people with various social institutions of metropolis.

All this allows to state that various initiatives are the object of cooperation of young people and various metropolis social structures, they provide identification, adoption, satisfaction of professional demand of students and besides serve as essential manifestation of modern culture [16].

In recent years, social innovation initiatives involving youth have emerged as a global phenomenon [10]. At present, the socio-cultural practice of a future teacher should perform not only subjective but also developing function. The researchers underline the importance of organizing research to situate discourse processes in socio-cultural practices [14]. In this regard, the socio-cultural and linguistic cultural space of metropolis allows to solve the formulated problems. In terms of content point of view, the interaction of language and cultures should have social orientation expressed in satisfaction of human demand to communicate in other society, and assumes development of linguistic socio-cultural competence [17, p. 142].

We assume that the development of youth initiatives in the frames of topic of initiative projects in socio-cultural practice (Fig. 1) is an important formation tool of professionalism, creativity, and value orientation of a future teacher. While implementing these projects (Table 1), future teachers acquire the required experience, varying the surrounding world, as their projects include ongoing collaborative partnership [18]. The main task of teachers is to provide assistance, to be a facilitator and promoter. Well-managed student projects can benefit policy and practice in a city as well as enhance the learning experience of the students involved $[19,20]$.

\section{Topics of initiative projects in 2018-2019 and 2019-2020 academic years}

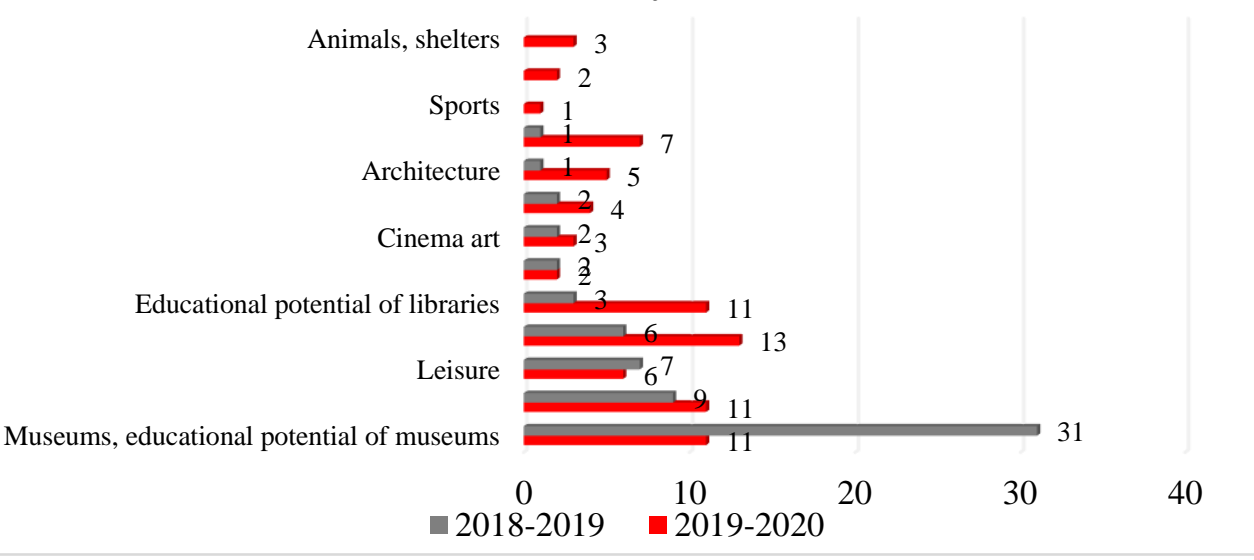

Fig. 1. Topics of initiative projects in 2018-2019 and 2019-2020 academic years. 
Table 1. Examples of implementation and support of students' initiatives during socio-cultural practice.

\begin{tabular}{|c|c|}
\hline$\frac{\text { Field and products of projects }}{\text { of urban youth initiatives }}$ & $\frac{\text { Examples of proactive actions }}{\text { of students: }}$ \\
\hline 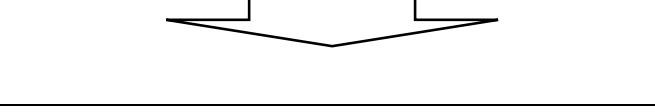 & $\begin{array}{l}\text { - independent selection of research scope } \\
\text { from available list; }\end{array}$ \\
\hline Scope of research: Theatrical art of metropolis & $\begin{array}{l}\text { - proposal of own research scopes; } \\
\text { - formulation of problems, research }\end{array}$ \\
\hline $\begin{array}{ll}\checkmark & \text { master classes, } \\
\checkmark & \text { types of theaters and theatre genres; } \\
\checkmark & \text { content comparison of the play and the work; } \\
\checkmark & \text { theatrical practices during studying foreign } \\
\text { languages; } \\
\checkmark \quad \text { best plays for foreign students studying the } \\
\text { Russian language }\end{array}$ & $\begin{array}{l}\text { objectives; } \\
\text { - } \quad \text { searching for possible project recipients; } \\
\text { - } \quad \text { proposal of own research schedule; } \\
\text { - } \quad \text { serecasting research results; } \\
\text { cooperation; } \\
\text { - } \quad \text { selection of ready final product of project } \\
\text { and its presentation and defense; }\end{array}$ \\
\hline $\begin{array}{l}\text { Product: top-list, reviews, articles for MCU, } \\
\text { guidance }\end{array}$ & Toolkit for support of initiatives: \\
\hline Scope of research: Museums & - $\quad$ information suppo \\
\hline $\begin{array}{l}\checkmark \quad \text { visiting program for little-known museum } \\
\text { exhibits; } \\
\checkmark \quad \text { program of popular sites for foreign guests, } \\
\checkmark \quad \text { availability of museums for disabled people, } \\
\text { families with little children, etc. } \\
\checkmark \quad \text { comparison of museums }\end{array}$ & $\begin{array}{l}\text { students during orientation and final } \\
\text { conferences of practice; } \\
\text { - consultations with head and experts; } \\
\text { - collective discussion of research results } \\
\text { in group. }\end{array}$ \\
\hline $\begin{array}{c}\text { Product: rating of museums, } \\
\text { routing, program }\end{array}$ & $\begin{array}{c}\text { Sites for exchange } \\
\text { with students' initiatives }\end{array}$ \\
\hline Scope of research: Leisure & 0 \\
\hline $\begin{array}{l}\checkmark \quad \text { rock shows, concerts of classical and } \\
\text { contemporary music; } \\
\checkmark \quad \text { festivals of pop culture; dance studios; ballet } \\
\text { schools }\end{array}$ & $\begin{array}{l}\text { discussions, startups; } \\
\text { - scientific publications on project } \\
\text { results; } \\
\text { - performance at student competitions; }\end{array}$ \\
\hline Product: rating list & - development of electronic resources on \\
\hline Scope of research: Shopping malls & \\
\hline $\begin{array}{ll}\checkmark & \text { Mall as a culture and education space; } \\
\checkmark & \text { quality of food courts; } \\
\checkmark & \text { marketing methods; } \\
\checkmark & \text { unusual books }\end{array}$ & Properties of youth initiatives \\
\hline Product: top-list, review map & \\
\hline Scope of research: Urban library spaces & novelty; \\
\hline $\begin{array}{ll}\checkmark & \text { literature preferences of people of various } \\
\text { ages; } & \\
\checkmark & \text { bookshelf of philologist; } \\
\checkmark & \text { library as an educational snace }\end{array}$ & $\begin{array}{ll}\text { - } & \text { voluntariness; } \\
\text { - } & \text { civic orientation; } \\
\text { - } & \text { mobility; } \\
\text { - } & \text { interaction and co }\end{array}$ \\
\hline Pry as an equcational space & - dialogue \\
\hline
\end{tabular}




\begin{tabular}{|c|c|}
\hline Scope of research: Architecture & \\
\hline $\begin{array}{ll}\checkmark & \text { available environment; } \\
\checkmark & \text { psychic geography }\end{array}$ & $\begin{array}{l}\text { Estimation criteria } \\
\text { of youth initiatives }\end{array}$ \\
\hline Product: map, quest route & $\square$ \\
\hline Scope of research: Social networks, blogs, sites & \\
\hline$\checkmark \quad$ Content of official and fan VK communities & - Importance and imnovations, \\
\hline Product: analysis & - reflection of results of initiative \\
\hline Scope of research: Charity and volunteering & actions; \\
\hline $\begin{array}{ll}\checkmark & \text { how to organize a charity event; } \\
\checkmark & \text { volunteering motives }\end{array}$ & $\begin{array}{l}\text { - } \quad \text { opportunity of translation; } \\
\text { creation of partner links; }\end{array}$ \\
\hline Product: manual, interview & - $\quad$ influence of personal and professional \\
\hline Scope of research: Cinema art & growth of students; \\
\hline $\begin{array}{l}\checkmark \text { networks of Moscow cinemas oriented at } \\
\text { students studying foreign languages }\end{array}$ & external estimation \\
\hline Product: reviews, booklet & \\
\hline Scope of research: Ecology & \\
\hline environmental safety of city & \\
\hline Product: presentation & \\
\hline $\begin{array}{l}\text { Scope of research: Animals in urban } \\
\text { environment, shelters }\end{array}$ & \\
\hline $\begin{array}{l}\checkmark \quad \text { the influence of animals on emotional } \\
\text { sphere of children; } \\
\checkmark \quad \text { volunteering in animal shelters }\end{array}$ & \\
\hline $\begin{array}{l}\text { Product: recommendation of parents, volunteer } \\
\text { manual }\end{array}$ & \\
\hline Scope of research: Nonformal education & \\
\hline $\begin{array}{l}\checkmark \quad \text { projects of nonformal education in the field } \\
\text { of foreign languages, media education }\end{array}$ & \\
\hline Product: booklet & \\
\hline Scope of research: Sports & \\
\hline sports sites in city & \\
\hline$\checkmark$ & \\
\hline
\end{tabular}

\section{Discussion}

The data mentioned above evidence the interest of youth in socially meaningful problems of society and intention of students to make own contribution to their solution. Demand in investigations into this or that sphere and its components can vary depending on subjective reasons, as well as on academic year. However, the method of support of students' initiatives in the frames of socio-cultural practice developed in Moscow City University, allows to manage successfully the projects of various specialization. The obtained product of the practice is directly affected by the applied toolkit of support of youth initiatives, opportunity of interaction, as well as translation of ideas and results.

\section{Conclusion}

Youth is the future of the country, its support and backbone; therefore, it is required to support the students' initiatives, to provide assistance in their implementation, and the university should become a promoter of innovation activities that constitutes a solid supporter to 
develop new products, services and new business models [13]. Socio-cultural practice provides the opportunity for students to show their activity.

\section{References}

1. G.J. Kelly, J.L. Green, Theory and Methods for Sociocultural Research in Science and Engineering Education (Routledge, New York, 2019)

2. N.V. Yazykova, Foreign languages at school, 5, 12-17 (2019).

3. Order of the Ministry of Education and Science of Russia "On the approval of the Federal State educational standard of higher education - bachelor's degree in the direction of training 44.03.01 Pedagogical education" No. 121 dated 22.02.2018. [Online]. Available:

http://publication.pravo.gov.ru/Document/View/0001201601140005

4. J. Davis, Developing Cultural and Social Competencies and Dispositions through Structured Engagements with Community-based Organizations, in EDULEARN16 Proceedings. 8th International Conference on Education and New Learning Technologies, 4-5 July 2016, Barcelona, Spain, 9312 (2016). http://dx.doi.org/10.21125/edulearn.2016.0017

5. O.V. Afanasyeva, K.M. Baranova, Correctness and political correctness of the teacher's speech in English lessons, in Pedagogical discourse: the quality of the teacher's speech. Materials of the II All-Russian Conference, L.G. Vikulova (Ed.), Moscow City Pedagogical University, May 27-29, 2020, Moscow, Russia, 17-22 (2020)

6. Ye.G. Tareva, Preparing students for socio-cultural and socio-linguistic variability of intercultural communication, in the collection: Foreign philology. Social and national variability of language and literature. Materials of the III International Scientific Congress, Ye.V. Polkhovskaya (Ed.), Crimean Federal University named after V.I. Vernadsky, 02-20 April 2018, Simferopol, Republic of Crimea, Russia, 58-63 (2018)

7. G.V. Sorokovykh, T.I. Zharkova (Eds.), Teacher, personality, reformer (Perspektiva, Moscow, 2020)

8. S.L. Rubinshtein, Fundamentals of General Psychology in 2 Volumes, Vol. 1 (Pedagogika, Moscow, 1989)

9. G.V. Sorokovykh, The program-concept of the formation of the subject of education in the process of learning a foreign language in a nonlinguistic university (Tezaurus, Moscow, 2004)

10. I.S. Yakimanskaya, Psychological journal, 24(2), 87-95 (2003)

11. T.I. Shamova, Activation of the teaching of schoolchildren (Pedagogika, Moscow, 1982)

12. P.V. Sysoev, Language and Culture, 43, 261-281 (2018). https://doi.org/10.17223/19996195/43/16

13. A.H. Maslow, A Theory of Human Motivation. A Psychological Research that Helped Change the Field for Good (General Press, New Dehli, 2019)

14. M. Heidegger, Country Path Conversations (Indiana University Press, Bloomington and Indianapolis, 2016)

15. Information Resources Management Association, Teacher Education: Concepts, Methodologies, Tools, and Applications (IGI Global, 2016, 1663) 
16. R. Hambleton, Leading the Inclusive City: Place-Based Innovation for a Bounded Planet (Policy Press, Southampton, 2015)

17. G.V. Sorokovykh, N.G. Pribylova, Psikhologiya obrazovaniya v polikulturnom prostranstve, 32(4), 141-144 (2015)

18. A.X. Oña Serrano, O. Pantoja Díaz, The University and the Social Entrepreneurship, in INTED2016 Proceedings. 10th International Technology, Education and Development Conference, 7-9 March 2016, Valencia, Spain, 3510-3515 (2016). http://dx.doi.org/10.21125/inted.2016.1830

19. S. Bastien, H.B. Holmarsdottir, Youth as Architects of Social Change. Global Efforts to Advance Youth-Driven Innovation (Palgrave Macmillan, Cham, 2017)

20. I. Ezema, A. Opoko, O. Olatunji, Bridging the Gap between Education and Practice: the "Town and Gown" Initiative of Covenant University, Nigeria, in EDULEARN17 Proceedings. 9th International Conference on Education and New Learning Technologies, 3-5 July 2017, Barcelona, Spain, 2889-2895 (2017). http://dx.doi.org/10.21125/edulearn.2017.1605 